\title{
State Universities Push the Limits of Eleventh Amendment Sovereign Immunity at the Federal Circuit
}

\author{
By CHRISTOPHER M. HOLMAN
}

I N 2014 A COMPANY CALLED GENSETIX OBTAINED an exclusive license to patents that were assigned to the University of Texas MD Anderson Cancer Center (UT) and directed to methods of modifying a patient's immune system to kill cancer cells. At the time the inventions were developed the named inventor of the patents was employed at UT, but by 2011 he had moved to Baylor University, where he is currently a professor.

In 2017, Gensetix sued Baylor for infringement of the patents. ${ }^{1}$ In its complaint, Gensetix alleged that the named inventor "continued and continues to use technology that infringes one or more claims of the [p]atents-in-[s]uit ... as part of his work at" Baylor. Before filing its complaint, Gensetix requested that UT join as a co-plaintiff, but UT declined. Gensetix therefore named UT as an involuntary plaintiff pursuant to Federal Rule of Civil Procedure (FRCP) 19(a). UT filed a motion seeking to dismiss itself from the lawsuit, arguing that the university is a sovereign state entity under Texas law and that, under the Eleventh Amendment, the district court lacked subject matter jurisdiction over UT.

For its part, Baylor argued that: (1) UT is a necessary party because it owns the patents-in-suit and transferred less than all substantial patent rights to Gensetix; (2) UT cannot be joined as an involuntary plaintiff because, as an entity of the State of Texas, it is entitled to Eleventh Amendment sovereign im-

Christopher M. Holman is a Professor of Law at the University of Missouri-Kansas City School of Law; a Senior Fellow at the Center for the Protection of Intellectual Property at the Antonin Scalia Law School, George Mason University; and the Executive Editor of Biotechnology Law Report. munity; and (3) the FRCP 19(b) factors weigh in favor of dismissing the suit, rather than proceeding in UT's absence.

The district court granted UT's motion to dismiss, finding that the Eleventh Amendment prohibited involuntary joinder of UT as an "arm" of the state of Texas, and that under FRCP 19(a) and (b), respectively, UT was a "necessary" and "indispensable" party, and that the suit could not proceed in the university's absence.

On appeal, a fractured panel of the Federal Circuit affirmed-in-part and reversed-in-part. Two of the judges on the panel agreed with the district court that the Eleventh Amendment barred the involuntary joinder of UT as a plaintiff. However, a different pair of judges ruled that the district court had erred in dismissing the lawsuit under FRCP 19(b), and that Gensetix should be allowed to proceed with its lawsuit without UT. So Gensetix dodged a bullet, but just barely, given that two of the four judges that heard the case (the district court judge and one of the judges on the panel) would have denied Gensetix the ability to enforce its exclusively licensed patents as a consequence of the licensor's Eleventh Amendment sovereign immunity.

The Eleventh Amendment of the U.S. Constitution grants the states sovereign immunity from being sued in federal court, but in recent years state universities have asserted the immunity in a wide variety of contexts extending well beyond mere immunity from being forced to defend themselves in

\footnotetext{
${ }^{1}$ Gensetix, Inc. v. Bd. of Regents of Univ. of Texas Sys., 966 F.3d 1316 (Fed. Cir. 2020) (an edited version of this decision appears elsewhere in this issue of Biotechnology Law Report).
} 
a lawsuit. The case discussed above, Gensetix v. $B d$. of Regents of Univ. of Texas Sys., provides a good example of this, with the university essentially asserting Eleventh Amendment immunity as a means of preventing its exclusive licensee from suing another Texas university for infringing the university's patents. In other cases, discussed later in this article, one university has successfully invoked the immunity to block a collaborative research partner from challenging the inventorship of a patent arising out of the research, and another has used it to dictate venue in its own patent enforcement efforts. However, there are also a number of cases in which the court has turned back attempts by universities to expand the scope of sovereign immunity. In one case, for example, a state university sought unsuccessfully to assert Eleventh Amendment immunity as a means to block an adversary from appealing a patent interference decision that went in the university's favor. State universities have also been thwarted in attempts to shield their patents from inter partes review (IPR) or patent eligibility challenges under Section 101 of the Patent Act by asserting sovereign immunity.

This article begins with an overview of the Eleventh Amendment and the law surrounding it, including decisions of the Supreme Court that have struck down attempts by Congress to abrogate sovereign immunity with respect to federal intellectual property laws, including patent law. The article then summarizes and discusses a number of Federal Circuit decisions involving assertions of Eleventh Amendment immunity by state universities and relating to patent law, beginning with some decisions in which the university succeeded, followed by an even larger number of decisions in which the university was rebuffed. The article concludes with some discussion of the practical implications of the case law, particularly for those who have exclusively licensed a university patent, or are considering doing so.

\section{THE ELEVENTH AMENDMENT AND STATE SOVEREIGN IMMUNITY}

The Eleventh Amendment provides that " $[\mathrm{t}] \mathrm{he}$ Judicial power of the United States shall not be construed to extend to any suit in law or equity, commenced or prosecuted against one of the United States by Citizens of another State, or by Citizens or Subjects of any Foreign State." ${ }^{2}$ Under the Eleventh Amendment, states enjoy a sovereign immunity and cannot be compelled to submit to the jurisdiction of federal courts. Significantly, however, the amendment does not create a nonwaivable limit on the Federal Judiciary's subject matter jurisdiction. "A state can waive its Eleventh Amendment protection and allow a federal court to hear and decide a case commenced or prosecuted against it." ${ }^{3}$ Eleventh Amendment sovereign immunity encompasses not only actions in which a state is named as a defendant, but also certain actions against state agents and state instrumentalities, including state universities. ${ }^{4}$ In the context of patent litigation in particular, the Federal Circuit has repeatedly held that state universities are an "arm of the state," and thus enjoy the privilege of state sovereign immunity under the Eleventh Amendment. ${ }^{5}$

In Alden v. Maine, the Supreme Court observed that states enjoy immunity from lawsuits brought by private parties as a "fundamental aspect of the sovereignty which the States enjoyed before the ratification of the Constitution, and which they retain today." "Although commonly referred to as "Eleventh Amendment immunity," the Supreme Court has clarified that "the sovereign immunity of the States neither derives from nor is limited by, the terms of the Eleventh Amendment."7 "The preeminent purpose of state sovereign immunity is to accord States the dignity that is consistent with their status as sovereign entities," while collaterally "serv[ing] the important function of shielding state treasuries."

\section{Unsuccessful legislative attempts}

to abrogate state sovereign immunity

Congress attempted to legislatively abrogate state sovereign immunity with respect to federal patent law in the Patent and Plant Variety Protection Remedy Clarification Act of $1992,{ }^{9}$ but in 1999 the

${ }^{2}$ U.S. Const. amend. XI.

${ }^{3}$ Idaho v. Coeur d'Alene Tribe of Idaho, 521 U.S. 261, 267 (1997).

${ }^{4}$ Regents of the Univ. of Cal. v. Doe, 117 S.Ct. 900, 903 (1997); see also BV Eng'g v. Univ. of Cal., 858 F.2d 1394, 1395 (9th Cir. 1988).

${ }^{5}$ See Regents of the Univ. of New Mexico v. Knight, 321 F.3d 1111, 1124 (Fed. Cir. 2003) (recognizing the status of a state university as an arm of the state); Xechem Int'l, Inc. v. Univ. of Tex. M.D. Anderson Cancer Ctr., 382 F.3d 1324 (Fed. Cir. 2004).

${ }^{6}$ Alden v. Maine, 527 U.S. 706, 713 (1999).

${ }^{7}$ Id.; see Seminole Tribe of Fla. v. Florida, 517 U.S. 44, 54 (1996).

${ }^{8}$ Fed. Mar. Comm'n v. S.C. State Ports Auth., 535 U.S. 743, 760, 765 (2002).

${ }^{9}$ Pub. L. No. 102-560, 106 Stat. 4230 (codified at 35 U.S.C. $\S \S 271(h), 296)$. 
Supreme Court struck down the legislation as a violation of the Eleventh Amendment in Florida Prepaid Postsecondary Education Expense Board v. College Savings Bank. ${ }^{10}$ The Court held that Eleventh Amendment immunity may be abrogated "only where the State provides no remedy, or only inadequate remedies, to injured patent owners for its infringement of their patent," thus resulting in a deprivation of property without due process result, and thereby invoking the Fourteenth Amendment. ${ }^{11}$ The Court pointed to a lack of any "pattern of patent infringement by the States," suggesting that a legislative remedy had not been shown to be necessary. ${ }^{12}$

In another case decided the same day, College Savings Bank v. Florida Prepaid Postsecondary Education Expense Board, the Court also struck down the legislative abrogation of state immunity from suit under trademark laws. ${ }^{13}$ The Federal Circuit has recognized that "in College Savings the Court explained that waiver of the Eleventh Amendment right to be immune from the authority of federal courts can occur in only two circumstances: first, if the state on its own initiative invokes the jurisdiction of the federal courts; and second, upon a clear declaration by the state of its intent to submit to federal jurisdiction." ${ }^{14}$ In College Savings, responding to the argument that sovereign immunity should be deemed waived when a state enters into commercial activity, the Court pointed out that the Eleventh Amendment does not make that distinction, and that such a distinction is inapplicable because "the constitutional role of the States sets them apart from other employers and defendants." 15 The Court stressed in College Savings that a state's waiver of Eleventh Amendment rights cannot be imposed or implied based on a state's entry into commerce, but must be founded on a "clear declaration" by the state of its intent to submit to federal jurisdiction.

In Allen v. Cooper, a decision that should have surprised no one, the Supreme Court recently struck down federal legislation purporting to strip states of sovereign immunity with respect to federal copyright laws. ${ }^{16}$

\section{The Ex Parte Young doctrine}

Even under circumstances in which the state itself enjoys Eleventh Amendment immunity, a lawsuit can sometimes be maintained against state officials under the Ex Parte Young doctrine. In Ex Parte Young, the Supreme Court held that if a state official were to seek to enforce an unconstitutional act, and thus came into conflict with the supreme authority of the Constitution and was thereby stripped of his official capacity, then the state's mantle of sovereign immunity would not be available to insulate his actions. ${ }^{17}$ The Supreme Court has also noted that " $[t] 0$ ensure the enforcement of federal law[,] the Eleventh Amendment permits suits for prospective injunctive relief against state officials acting in violation of federal law." ${ }^{18}$ Under the Ex Parte Young doctrine, remedies for violations of federal law can only be extended to future injunctive relief, not "retroactive monetary relief." 19 To analyze an Ex Parte Young claim, "a court need only conduct a "straightforward inquiry into whether [the] complaint alleges an ongoing violation of federal law and seeks relief properly characterized as prospective." 20

Thus, continuing prospective violations of a federal patent right by state officials may be enjoined by federal courts under the Ex Parte Young doctrine; however, the Eleventh Amendment precludes the plaintiff from obtaining monetary damages from individual defendants in their official capacities. ${ }^{21}$ Moreover, there must be a connection between the state officer and the enforcement of the act, otherwise the suit will merely make him a representative of the state, thereby improperly making the state a party to the suit. ${ }^{22}$ "A nexus between the violation of federal law and the individual accused of violating that law requires more than simply a broad general obligation to prevent a violation." ${ }^{23}$ When a

${ }^{10}$ Florida Prepaid Postsecondary Education Expense Board v. College Savings Bank, 527 U.S. 627 (1999).

${ }^{11}$ Id. at 643 .

${ }^{12} \mathrm{Id}$. at 640 .

${ }^{13}$ College Savings Bank v. Florida Prepaid Postsecondary Education Expense Board, 527 U.S. 666 (1999).

${ }^{14}$ Xechem Int'l, Inc. v. Univ. of Tex. M.D. Anderson Cancer Ctr., 382 F.3d 1324, 1329 (Fed. Cir. 2004) (citing Coll. Sav.

Bank v. Fla. Prepaid Postsecondary Educ. Expense Bd., 527 U.S. 666, 675-76 (1999)).

${ }^{15} \mathrm{Id}$. at $685-86$.

${ }^{16}$ Allen v. Cooper, 140 S. Ct. 994 (2020) (striking down provisions of the Copyright Remedy Clarification Act of 1990 (CRCA) that would have abrogated State sovereign immunity in copyright infringement cases).

${ }^{17}$ Ex Parte Young, 209 U.S. 123, 159-60 (1908).

${ }^{18}$ Frew v. Hawkins, 540 U.S. 431, 437 (2004).

${ }^{19}$ Pennhurst State Sch. \& Hosp. v. Halderman, 465 U.S. 89, 102-03 (1984).

${ }^{20}$ Verizon Md., Inc. v. Pub. Serv. Comm'n of Md., 535 U.S. 635, 645 (2002).

${ }^{21}$ Pennington Seed, Inc. v. Produce Exch. No. 299, 457 F.3d 1334 (Fed. Cir. 2006).

${ }^{22} 209$ U.S. at 157.

${ }^{23}$ Pennington Seed, Inc. v. Produce Exch. No. 299, 457 F.3d 1334 (Fed. Cir. 2006). 
violation of federal law is alleged, the state official whose actions violate that law is the rightful party to the suit and prospective injunctive relief can only be had against him. ${ }^{24}$

\section{THE ELEVENTH AMENDMENT AND STATE UNIVERSITIES AT THE FEDERAL CIRCUIT}

The Federal Circuit has held that the question of Eleventh Amendment waiver is a matter of Federal Circuit law, pointing to the policy interests both in "bringing about uniformity in the area of patent law" and in "minimizing confusion and conflicts in the federal judicial system." 25 For example, "[were the court] to apply regional circuit law, the counterclaims that a defendant in a state-initiated patent suit would be entitled to assert, and for which the state would be potentially liable, might vary with the regional circuit in which the case originated." 26 The court applies a de novo standard of review to this question of law. ${ }^{8}$

\section{Successful assertions of Eleventh Amendment immunity}

This section of the article discusses several Federal Circuit decisions in which state universities have successfully invoked Eleventh Amendment immunity in a case involving patent law, yet outside the context of a state university being named as a defendant in a patent infringement lawsuit.

Correction of inventorship. In Xechem Int'l, Inc. v. Univ. of Tex. M.D. Anderson Cancer Ctr., the Federal Circuit held that Eleventh Amendment immunity applies to a cause of action seeking correction of inventorship on an issued patent. ${ }^{27}$ The case arose out of a Sponsored Laboratory Study Agreement between Xechem, a biopharmaceutical company, and the University of Texas M.D. Anderson Cancer Center. Under the agreement, Xechem provided the university with financial and technical support, for the purpose of developing a pharmaceutical formulation that would enhance the solubility, and thereby the effectiveness, of the cancer drug paclitaxel. Under a Patent and Technology License Agreement, Xechem received the exclusive worldwide license to manufacture and market these paclitaxel formulations, and Xechem agreed to pay certain continuing sums and a royalty. The university obtained two patents relating to the project, both of which named a university scientist as the sole inventor.

After the first patent issued, however, the university notified Xechem that it considered the license agreement have terminated automatically due to Xechem's alleged insolvency, and that any use of this technology by Xechem would be deemed to constitute patent infringement. Xechem responded by filing suit in federal court, presenting several counts, including one seeking correction of inventorship under 35 U.S.C. $\$ 256$ to add the company's CEO. The district court dismissed the complaint under the Eleventh Amendment.

On appeal, Xechem raised several arguments: (1) that the Eleventh Amendment does not bar an action to correct inventorship under 35 U.S.C. § 256, because the correction of inventorship will change the ownership of the patents, thereby raising property issues cognizable under the Due Process Clause of the Fourteenth Amendment; (2) that correction of inventorship does not require participation or consent of the owner of the patent, and thus can proceed in federal court despite the university's objection; (3) that because the university's employee applied for and was granted these patents by the United States Patent and Trademark Office (PTO), a federal agency, the university had consented to federal jurisdiction, at least for correction of the identity of the applicant; and (4) that patents are a gift or gratuity granted by the federal government, and that the university's acceptance of the patents is a waiver of Eleventh Amendment immunity.

The Federal Circuit rejected all of these arguments, holding that Eleventh Amendment immunity applies to a lawsuit seeking correction of inventorship on a patent. The court noted that in College Savings the Supreme Court held that "a state's waiver of Eleventh Amendment rights cannot be imposed or implied based on a state's entry into commerce, but must be founded on a "clear declaration" by the state of its intent to submit to federal jurisdiction," and that the University had not made such a declaration simply by virtue of it having entered into its various relationships and contracts with Xechem. The Federal Circuit also held that in College Savings the Supreme Court had "negated the argument that a state's voluntary participation in activities controlled by federal statute [such as applying for and receiving a patent] imposes a consent to suit arising from those activities.... [T] he argument must be rejected that a state's entry into the

\footnotetext{
${ }^{24} I d$.

${ }^{25}$ Regents of Univ. of New Mexico v. Knight, 321 F.3d 1111 (Fed. Cir. 2003).

${ }^{26} I d$.

${ }^{27}$ Xechem Int'l, Inc. v. Univ. of Tex. M.D. Anderson Cancer Ctr., 382 F.3d 1324 (Fed. Cir. 2004).
} 
patent system is a constructive waiver of immunity for actions in federal court against the state under the patent law."

Regarding Xechem's argument that the grant of a patent is a "gift or gratuity" by the government, the court pointed out that the grant of a patent is not a disbursement of governmental largesse without consideration, but rather is conditioned on the creation and public disclosure of a new and useful invention, and that Supreme Court precedent has foreclosed the argument that by obtaining patents a state has constructively waived its Eleventh Amendment immunity as to any federal proceeding involving those patents.

The Federal Circuit questioned Xechem's assertion in its pleadings that inventorship can be corrected only in federal court, noting that "ownership issues are generally the province of state courts. Although the Federal Circuit has held that inventorship is determined under federal law, state courts can apply federal law to issues properly before the state court. Federal preemption of causes arising under the Patent Act does not include matters of ownership or license." Thus, the Federal Circuit suggested that Xechem might be able to find a remedy in state court. While the court noted that in Florida Prepaid the Supreme Court had recognized that possible state court remedies may be "uncertain" or "less convenient" or "might undermine the uniformity of patent law," it nonetheless held that uncertainty and other disadvantages flowing from a state's claim of Eleventh Amendment immunity did not necessarily deprive a patentee of property without due process of law. According to the Federal Circuit, in Florida Prepaid the Supreme Court stated that it was necessary to show that the state action "left [the patentee] without a remedy under state law," before the due process concerns of the Fourteenth Amendment could be implicated, which could potentially result in abrogation of the state's Eleventh Amendment immunity. In Xechem, the Federal Circuit found that such a showing had not been made.

More recently, in Ali v. Carnegie Inst. of Washington, a former employee of the University of Massachusetts (UMass) filed a pro se lawsuit in the District of Oregon ("Oregon court") against the Carnegie Institute of Washington (Carnegie) and UMass, alleging that they had erroneously omitted the plaintiff as a co-inventor on a handful of patents that the defendants co-owned. ${ }^{28}$ The patents are generally directed to methods of gene-specific inhibition through the use of double-stranded ribonucleic acid, and two of the named co-inventors of the claimed inventions, Dr. Andrew Fire of Carnegie and Dr. Craig C. Mello of UMass, received the Nobel Prize in Medicine in 2006 for these inventions. The plaintiff sought to be added as a coinventor to the patents-in-suit, as well as monetary damages from UMass for this alleged omission. The district court dismissed UMass on the ground that it is entitled to sovereign immunity under the Eleventh Amendment, and sua sponte transferred the case to the U.S. District Court for the District of Columbia ("DC court") because it lacked personal jurisdiction over Carnegie. The DC court then dismissed the case because UMass was a necessary party that could not be joined, ultimately entering judgment against the plaintiff. The Federal Circuit affirmed.

On appeal, the plaintiff argued that UMass had waived its sovereign immunity when, in return for federal funding under the Bayh-Dole Act, it allegedly signed a contract "controlled by and consistent with the Bayh-Dole Act," and expressly declared that it would be amenable to suit in federal court. The Federal Circuit rejected this argument, noting that as a state university UMass waives sovereign immunity under "only two circumstances: first, if the state on its own initiative invokes the jurisdiction of the federal courts; and second, upon a clear declaration by the state of its intent to submit to federal jurisdiction." The court went on to explain:

Here, UMass's alleged agreement to be subject to suit by the federal government under a contract controlled by and consistent with the Bayh-Dole Act cannot operate as a "clear declaration" that it waived its sovereign immunity as to [the plaintiff's] suit against it for damages arising from his alleged omission as a co-inventor of the patents-in-suit. We agree with the Oregon court that " $[\mathrm{t}]$ here is nothing in the Bayh-Dole Act that suggests waiver of sovereign immunity in federal court is a prerequisite to accepting funding under the [Bayh-Dole] Act, thereby permitting suit against a state in a $\S 256$ action," which also seeks to collect monetary damages. And, following the Supreme Court, we have rejected "the argument that a state waives its immunity by entering into arrangements controlled by federal law and reviewable only in federal court." Xechem, 382 F.3d at 1329 (relying on

${ }^{28}$ Ali v. Carnegie Inst. of Washington, 684 F. App'x 985 (Fed. Cir. 2017). 
Coll. Sav. Bank, 527 U.S. at 675, 119 S.Ct. 2219). Therefore, the Oregon court correctly declined to find any waiver of UMass's sovereign immunity. ${ }^{29}$

Judge Dyk filed an interesting concurring opinion, where he voiced the following concern:

Ordinary property disputes between individuals and state entities are resolved in state court. In these circumstances, the Eleventh Amendment, which bars suit only in federal courts, does not operate to leave the property owner without a remedy when a suit in federal court is dismissed.

Patent inventorship claims are different. A state law remedy is not available, and a claimant's only remedy lies in a federal cause of action under 35 U.S.C. $\S 256$ to correct inventorship. This is so because federal law ousts state courts of jurisdiction over inventorship claims. The statute provides that " $[\mathrm{n}] \mathrm{o}$ State court shall have jurisdiction over any claim for relief arising under any Act of Congress relating to patents." 28 U.S.C. $\S$ 1338(a). 1 The statute instead prescribes exclusive jurisdiction in federal courts. See id. Under these circumstances, it seems to me particularly harsh to hold that the federal actionin which the relief sought is directed to the Director of the Patent Office-cannot proceed without the state entity as a party. I note that in University of Utah v. MaxPlanck-Gesellschaft Zur Forderung Der Wissenschaften E.V., 734 F.3d 1315, 1328 (Fed. Cir. 2013), we allowed the federal action to proceed without the state entity.

Thus, while I join the majority opinion, it remains for us to determine in another case how the Rule 19(b) factors should apply to a claim for inventorship, given the lack of any alternative remedy. (These concerns may not, of course, extend to a damages claim for misappropriation of patent rights, since a state court remedy may well be available). ${ }^{30}$

Immunity extends to where a suit may be filed. In Tegic Commc'ns Corp. v. Bd. of Regents of Univ. of Texas Sys., the Federal Circuit held that a state university that sued a number of cellular telephone companies for patent infringement had not waived Eleventh Amendment immunity with respect to a declaratory judgment lawsuit filed by a company that had not been directly sued by the university, even though the company had an interest in the case because in had supplied the defendants with the software product which was the basis of the alleged infringement. ${ }^{31}$ The case arose out of the University of Texas's decision to file suit in the Western District of Texas, charging 48 cellular-telephone companies with infringement of a patent directed to a method of inputting text into a device keyboard, wherein the device software recognizes the text and predicts the word the user intends to type. Tegic, a corporation of the State of Washington, had sold and licensed text-input software, entitled "T9 Text Input," to 39 of the 48 cellular-phone company defendants. On behalf of its customers and licensees, Tegic brought a declaratory suit against the University in the Western District of Washington, seeking a declaration that the patent was invalid and unenforceable, and that the T9 software does not infringe, contribute to infringement, or induce infringement of the patent. Tegic alleged that the University's action in Texas, ostensibly directed against the cellular-phone manufacturers, was actually directed against Tegic as the manufacturer and licensor of the software that, in combination with the cellular-phone hardware, allegedly infringed the university's patent.

The University filed with the district court in Washington a covenant not to sue Tegic for past, present, or future acts of infringement, and thereafter filed a motion to dismiss on the ground that the district court lacked subject matter jurisdiction, given that the covenant precluded any case or controversy between the University and Tegic. The University also stated that, as an arm of the State of Texas, it was not subject to the jurisdiction of the federal courts and was protected from Tegic's suit by Eleventh Amendment immunity. The district court granted the motion to dismiss, on the ground that the University is immune from suit in the federal courts pursuant to the Eleventh Amendment, and had not waived its immunity as to Tegic's declaratory judgment action. The Federal Circuit affirmed.

The Federal Circuit held that the University's filing of the Texas action did not establish waiver with respect to "a new action brought by a different party in a different state and a different district court.

\footnotetext{
${ }^{29} I d$. at 992.

${ }^{30}$ Id. at 995 . University of Utah v. Max-Planck-Gesellschaft Zur Forderung Der Wissenschaften E.V. is discussed later in this article.

${ }^{31}$ Tegic Commc'ns Corp. v. Bd. of Regents of Univ. of Texas Sys., 458 F.3d 1335 (Fed. Cir. 2006).
} 
Tegic argued on appeal that waiver had been established by the University's invocation of federal jurisdiction by filing suit against Tegic's customers/ licensees in the Western District of Texas. But the Federal Circuit pointed out that the Supreme Court has stressed that a "State's constitutional interest in immunity encompasses not merely whether it may be sued, but where it may be sued." ${ }^{32}$ The court found that Regents of the University of California v. Eli Lilly \& Co., wherein the Federal Circuit affirmed the transfer of a state's action from the Northern District of California to the Southern District of Indiana, was inapposite to the present action because in Regents of $U C$ "there was no claim or counterclaim against the University; the state was plaintiff, and the issue was the prosecution of a suit not against the state (University) but against the defendant Lilly as the accused infringer." 33

Tegic further argued that under the "customer suit exception" a manufacturer's action to resolve patent infringement charges against its customers not only receives preferential treatment over a patent owner's earlier filed suit against the customers, but benefits from any waiver accompanying the earlier suit. But the Federal Circuit held that the customer suit exception, which is an exception to the general rule that favors the forum of the first-filed action, does not override the immunity provided by the Eleventh Amendment. The court noted that:

the guiding principles in the customer suit exception cases are efficiency and judicial economy, and Tegic has not established that it would be more efficient to enable this declaratory action to proceed in the State of Washington.... In addition, the University's express promise not to sue Tegic for any past, present, or future acts of infringement weighs strongly against favoring Tegic's manufacturer's action in Washington. We conclude that the customer suit exception does not impose a waiver of immunity on the facts of this case, without deciding whether, on appropriate facts, such a situation could arise.

Waiver of immunity in one suit does not extend to a separate lawsuit involving the same subject matter and the same parties. In A123 Sys., Inc. v. HydroQuebec, the Federal Circuit held that held that "where a waiver of immunity occurs in one suit, the waiver does not extend to an entirely separate lawsuit, even one involving the same subject matter and the same parties." 35 The litigation began when A123 Systems, Inc. (A123) filed suit against HydroQuebec (HQ) in the District of Massachusetts seek- ing a declaration of noninfringement and invalidity with respect to two patents that were assigned to the Board of Regents, The University of Texas System (UT) and licensed to HQ. A month later, HQ and UT jointly initiated an infringement suit against A123, among others, in the Northern District of Texas.

After A123 successfully requested a reexamination of both patents, the Texas action was stayed and the Massachusetts court dismissed A123's declaratory judgment action without prejudice to either party to reopen within 30 days following the termination of the reexaminations. A123 filed a timely motion to reopen the case, but the district court denied the motion, yielding jurisdiction over A123's declaratory judgment suit to the later-filed suit in Texas in light of its conclusion that A123's first-filed action, if reopened, would be subject to imminent dismissal for failure to join a necessary party. Specifically, the district court held that, by granting HQ only a field-of-use license, UT had transferred less than all substantial rights in the patents in suit to HQ, making UT a necessary party to A123's suit under the Federal Circuit's prudential standing requirement. The court then held that A123 could not join UT because UT had not waived Eleventh Amendment sovereign immunity in the Massachusetts court. Nonetheless, the court remarked, A123 had an adequate remedy because UT has waived Eleventh Amendment immunity in the Northern District of Texas by filing suit for infringement in that district.

On appeal, the Federal Circuit affirmed. In response to A123's argument that UT had waived its immunity from suit in this case when it filed suit against A123 for infringement of the same patents in Texas, the court pointed to its earlier decision in Biomedical Patent Management Corp. v. California, Department of Health Services (BPMC), in which the court held that a state university's participation in one lawsuit does not amount to a waiver of immunity in a separate lawsuit, even one involving the same patents. ${ }^{36}$

\footnotetext{
${ }^{32}$ Id. at 1342 (Citing Pennhurst State Sch. \& Hosp. v. Halderman, 465 U.S. 89, 99 (1984)).

${ }^{33}$ Id. Regents of the University of California v. Eli Lilly \& Co. is discussed later in this article.

${ }^{34} I d$. at 1343 .

${ }^{35}$ A123 Sys., Inc. v. Hydro-Quebec, 626 F.3d 1213 (Fed. Cir. 2010) (citing Biomedical Patent Management Corp. v. California, Department of Health Services, 505 F.3d 1328, 1339 (Fed. Cir. 2007)).

${ }^{36} I d$.
} 
In $B P M C$, BPMC had brought suit against the California Department of Health Services (DHS) in the Northern District of California, alleging patent infringement. The district court dismissed the suit based on DHS's assertion of Eleventh Amendment immunity. DHS, however, had intervened in an earlier suit against BPMC, later dismissed for improper venue, seeking a declaration of noninfringement and invalidity of the same patent. On appeal, BPMC argued that DHS's intervention in the earlier declaratory judgment suit had waived its immunity in the later suit. The Federal Circuit rejected this argument, holding that where a waiver of immunity occurs in one suit, the waiver does not extend to an entirely separate lawsuit, even one involving the same subject matter and the same parties. Following the BPMC precedent, the Federal Circuit held that UT's waiver of Eleventh Amendment immunity in the patent infringement suit filed in the Northern District of Texas did not result in a waiver of immunity in the declaratory judgment action filed in Massachusetts. Absent a waiver, UT could not be joined in the lawsuit. The court further held that UT was an indispensable party, and affirmed the district court's decision to dismiss the lawsuit pursuant to Federal Rule of Civil Procedure 19(b).

In support of the decision to dismiss the case, the Federal Circuit agreed with the district court's finding that maintaining jurisdiction over the A123's declaratory judgment suit posed a significant risk of prejudicing UT's interests in the patents, noting that:

Although HQ and UT undoubtedly share the same overarching goal of defending the patents' validity, neither that goal nor UT's decision to file suit jointly with HQ in Texas demonstrates that UT's interests will be adequately represented by HQ in this action. HQ and UT's interests in the patents, although overlapping, are not identical. HQ is a fieldof-use licensee, and a claim construction that serves its interests in obtaining an infringement judgment against A123 in this case may very well conflict with UT's interests in subject matter not licensed to HQ and in not risking the validity of its patents' claims. ${ }^{37}$

The court cited Schwarz Pharma, Inc. v. Paddock Labs., Inc. for the proposition that "a patent should not be placed at risk of invalidation by the licensee without the participation of the patentee." 38

The court also found that a judgment rendered without UT would be inadequate, because HQ is a field-of-use licensee and UT has retained nonoverlapping rights in the patents in suit, presenting a risk that UT may be able to assert infringement claims against A123 that HQ cannot, creating the risk of multiple lawsuits and inconsistent relief. Finally, the court found its significant that that because UT had waived immunity to suit in Texas, A123 would be able to assert counterclaims for a declaration of noninfringement and invalidity in that action.

Involuntary joinder. In Gensetix, the case discussed at the beginning of this article, a divided panel of the Federal Circuit held that a state university could invoke Eleventh amendment immunity in order to resist being compelled to join a patent infringement lawsuit brought by an exclusive licensee of the university's patent. Recall that UT had entered into an exclusive licensing agreement with Gensetix, but when Gensetix sued Baylor University for infringement of the patents UT refused to join as a plaintiff. ${ }^{39}$ The licensing agreement between UT and Gensetix expressly stated that UT was not waiving its sovereign immunity, and included terms that allow UT to initiate a suit on behalf of Gensetix, but not the other way around.

Gensetix sought to compel joinder, but the district court held that as an "arm" of the state of Texas, UT enjoyed sovereign immunity under the Eleventh Amendment of the U.S. Constitution, and could not be subjected to involuntarily joinder. The court then dismissed the lawsuit, finding that, under Federal Rules of Civil Procedure 19(b), UT was an indispensable party, and that considerations of "equity and good conscience" dictated that the cause of action should not proceed.

On appeal, Gensetix argued that Eleventh Amendment immunity bars suits brought by private citizens against the state, but does not the preclude coercive joinder of UT under Rule 19(a)(2), pointing out that joinder raises no claims or counterclaims against UT, thereby making sovereign immunity inapplicable. Gensetix also contended that courts have consistently held that a patentee who refuses to voluntarily join an infringement action initiated by its exclusive licensee can nonetheless be joined as an involuntary plaintiff.

\footnotetext{
${ }^{37} I d$. at 1221.

${ }^{38}$ Schwarz Pharma, Inc. v. Paddock Labs., Inc., 504 F.3d 1371, 1374 (Fed. Cir. 2007).

${ }^{39}$ Gensetix, Inc. v. Bd. of Regents of Univ. of Texas Sys., 966 F.3d 1316 (Fed. Cir. 2020).
} 
But the Federal Circuit rejected Gensetix's arguments, finding its attempt to limit the Eleventh Amendment to its text-i.e., to cases "against" a state-is contrary to the Supreme Courts statement in College Savings that "the sovereign immunity reflected in (rather than created by) the Eleventh Amendment transcends the narrow text of the Amendment itself." 40 The Supreme Court has also made clear that " $\mathrm{t}] \mathrm{h}$. Eleventh Amendment does not exist solely in order to prevent federal-court judgments that must be paid out of a State's treasury; it also serves to avoid the indignity of subjecting a State to the coercive process of judicial tribunals at the instance of private parties." 41

The Federal Circuit further noted that Gensetix had erroneously read Regents of UC to broadly hold that Eleventh Amendment immunity is inapplicable in all cases where the state is a plaintiff (even if involuntarily) and there are no counterclaims against the state. The court explained that:

Regents of $U C$ did not create a rule whereby parties may drag a sovereign into the federal court system against its will simply because there is no claim "against" the sovereign. Instead, our holding in that case was predicated on the state voluntarily submitting itself to federal court jurisdiction. [The] key distinction between Regents of $U C$ and the present case-that UT did not voluntarily invoke federal court jurisdiction-is dispositive. Unlike the sovereign in Regents of $U C$, UT did not attempt to avail itself of federal court jurisdiction, and, in fact, has repeatedly made clear that it does not want to participate in this litigation. It is immaterial that there are no claims against UT, or that UT is named an involuntary plaintiff rather than an involuntary defendant.... Rule 19(a)(2) cannot be used to drag an unwilling UT into federal court. ${ }^{42}$

Concurring in part and dissenting in part, Judge Newman wrote that, in her view, UT should have been compelled to join as a plaintiff. She argued that the Eleventh Amendment "does not insulate a State from its contractual obligations," and that by refusing to join as a co-plaintiff, the university had violated its agreement to "cooperate fully" with its licensee in the enforcement of the patents, and in so doing had "deprived its licensee of the agreed upon exclusivity."

The Federal Circuit then proceeded to reverse the district court's decision to dismiss the case, as discussed in more detail later in this article.
The Ex Parte Young doctrine. As discussed above, a lawsuit can sometimes be maintained against state officials under the Ex Parte Young doctrine. However, in Pennington Seed, Inc. v. Produce Exch. No. 299, the Federal Circuit denied a patent owner's attempt to invoke the doctrine and sue officials at the University of Arkansas. ${ }^{43}$ The lawsuit was originally filed against the University for infringement of a patent claiming a type of nontoxic fescue grass that does not adversely affect grazing livestock, but the case was dismissed based on Eleventh Amendment immunity. The patentees responded by filing an amended complaint naming as defendants the Chairman of the Board for the University System, the President of the University System, and the Chancellor of the University of Arkansas at Fayetteville (collectively "the University Officials"), asserting the Ex Parte Young doctrine. The district court dismissed the amended complaint, again based on Eleventh Amendment immunity, and the Federal Circuit affirmed.

On appeal, the patentee argued that the University Officials were liable for infringement because, due to their positions at the University, they supervised intellectual property activity, and had the ability to "stop an ongoing violation of federal law." However, the Federal Circuit held that:

Allegations that a state official directs a University's patent policy are insufficient to causally connect that state official to a violation of federal patent law-i.e., patent infringement. A nexus between the violation of federal law and the individual accused of violating that law requires more than simply a broad general obligation to prevent a violation; it requires an actual violation of federal law by that individual. The fact that a University Official has a general, state-law obligation to oversee a University's patent policy does not give rise to a violation of federal patent law. ${ }^{44}$

The court found that the patentee was, in essence, asking the federal courts to enjoin the University Officials from neglecting their job duties established by state law, but that a federal court cannot

\footnotetext{
${ }^{40}$ Citing Coll. Sav. Bank v. Fla. Prepaid Postsecondary Ed. Expense Bd., 527 U.S. 666, 687 (1999).

${ }^{41}$ Citing Seminole Tribe, 517 U.S. at 58

${ }^{42} 966$ F.3d at 1322-23.

${ }^{43}$ Pennington Seed, Inc. v. Produce Exch. No. 299, 457 F.3d 1334 (Fed. Cir. 2006).

${ }^{44}$ Id. at $1342-43$.
} 
enjoin a state official to perform his or her duty under state law. The court stated that:

A federal court's grant of relief against state officials on the basis of state law, whether prospective or retroactive, does not vindicate the supreme authority of federal law. On the contrary, it is difficult to think of a greater intrusion on state sovereignty than when a federal court instructs state officials on how to conform their conduct to state law. Such a result conflicts directly with the principles of federalism that underlie the Eleventh Amendment. ... A federal court may only enjoin ongoing activity that violates federal law. To hold otherwise would not only violate the principles of federalism and a state's sovereign immunity, but it would also be akin to a suit against the state itself. Thus, Pennington's claims against [the University Officials] were properly dismissed. ${ }^{45}$

\section{Failed assertions of Eleventh Amendment immunity}

This section of the article discusses several Federal Circuit decisions in which state universities have been unsuccessful in attempts to invoke Eleventh Amendment immunity in cases involving patent law.

Waiver by filing a lawsuit. It has long been established that a state waives its Eleventh Amendment immunity when it consents to federal court jurisdiction by voluntarily appearing in federal court. ${ }^{46} \mathrm{~A}$ state university can waive sovereign immunity by filing an infringement suit. In Regents of the Univ. of California v. Eli Lilly \& Co., for example, the Regents of the University of California (UC) filed a lawsuit against Eli Lilly \& Company (Lilly) in the Northern District of California, alleging infringement of UC patents relating to the recombinant production of human insulin. ${ }^{47}$ Lilly successfully moved for transfer of venue to the Southern District of Indiana, which held that Lilly's manufacture of human insulin was noninfringing, that some of the asserted claims were invalid, and that both patents were unenforceable. On appeal, UC argued that under the Eleventh Amendment the Indiana Court lacked jurisdiction to decide the case, and that by choosing to bring suit in the Northern District of California UC had waived its Eleventh Amendment immunity only in California federal courts.

The Federal Circuit disagreed, and held that:

[T]he Eleventh Amendment applies to suits "against" a state, not suits by a state. Thus, we need not determine whether UC waived its immunity only in California, because this case does not create an Eleventh Amendment jurisdictional issue concerning which the question of waiver even arises. This case only involves UC's patent infringement claims and Lilly's defenses; it does not involve any claim or counterclaim against UC that places $\mathrm{UC}$ in the position of a defendant. Accordingly, we conclude that the Eleventh Amendment does not deprive the Indiana district court of jurisdiction in this case. ${ }^{48}$

Compulsory counterclaims. In Regents of Univ. of New Mexico v. Knight, the Federal Circuit held that when a state waives sovereign immunity by filing a patent infringement lawsuit in federal court, the waiver extends to compulsory counterclaims filed by the defendant. ${ }^{49}$ A compulsory counterclaim (as defined by the Legal Information Institute's legal dictionary (Wex) is a:

[C]laim made by a defendant against a plaintiff that arises from the same transaction or occurrence as the plaintiff's claim. The claim is compulsory in this situation in that it must be raised in the defendant's answer, or it is waived. If defendant fails to assert counterclaim in his answer, he is thereafter precluded from asserting it against plaintiff in the plaintiff's pending action or in an independent action.

In UNM v. Knight, two former University of New Mexico (UNM) employees alleged that they should have been included as inventors on multiple UNM patents, and thus should have received royalties from the University pursuant to the UNM Patent Policy. The University responded by suing the two former employees, asking the court for a declaratory judgment regarding inventorship and ownership of

\footnotetext{
${ }^{45} I d$. at 1343.

${ }^{46}$ Clark v. Barnard, 108 U.S. 436, 447 (1883); see also Gunter v. Atl. Coast Line R.R., 200 U.S. 273, 284 (1906) ("[W]here a State voluntarily becomes a party to a cause and submits its rights for judicial determination, it will be bound thereby and cannot escape the result of its own voluntary act by invoking the prohibition of the Eleventh Amendment.").

${ }^{47}$ Regents of the Univ. of California v. Eli Lilly \& Co., 119 F.3d 1559 (Fed. Cir. 1997).

${ }^{48} I d$. at $1564-1565$.

${ }^{49}$ Regents of Univ. of New Mexico v. Knight, 321 F.3d 1111 (Fed. Cir. 2003).
} 
the patents. The former employees asserted counterclaims seeking money damages for royalties owed under the agreement, and the university moved for dismissal of the counterclaims, asserting sovereign immunity under the Eleventh Amendment. The district court dismissed the counterclaims, but on appeal the Federal Circuit reversed. The court noted that it has long been established that the state waives its Eleventh Amendment immunity when it consents to federal court jurisdiction by voluntarily appearing in federal court, and that UNM had "unmistakably consented to federal court jurisdiction" when it filed suit against the former employees.

The Federal Circuit held that UNM's waiver of sovereign immunity extended to compulsory counterclaims. The court found in particular that counterclaims for royalties under an agreement relating to patents should be litigated in the same cause of action as a claim for a declaration of ownership of those patents, and that the state should be considered to have consented to such. The court cited to the Supreme Court's decision in Lapides v. Board of Regents of the University System of Georgia, in which the Court addressed the inconsistency and unfairness that could result from allowing a state that voluntarily avails itself of the federal courts to simultaneously claim immunity under the Eleventh Amendment. ${ }^{50}$ In Lapides the Court explained:

It would seem anomalous or inconsistent for a State both (1) to invoke federal jurisdiction, thereby contending that the "Judicial power of the United States" extends to the case at hand, and (2) to claim Eleventh Amendment immunity, thereby denying that the "Judicial power of the United States" extends to the case at hand. And a Constitution that permitted States to follow their litigation interests by freely asserting both claims in the same case could generate seriously unfair results. ${ }^{51}$

The Federal Circuit found that the Supreme Court's rationale applied to the facts of the present case, in which "seriously unfair results" could obtain if a state were permitted to file suit in federal court seeking to enforce a right to ownership of patents arising from certain contractual agreements and conduct and, at the same time, to claim immunity from liability for royalties or other compensation arising from those same contracts and conduct. The court explained that:

Because a state as plaintiff can surely anticipate that a defendant will have to file any compulsory counterclaims or be forever barred from doing so, it is not unreasonable to view the state as having consented to such counterclaims. We thus hold that when a state files suit in federal court to enforce its claims to certain patents, the state shall be considered to have consented to have litigated in the same forum all compulsory counterclaims, i.e., those arising from the same transaction or occurrence that gave rise to the state's asserted claims. Accordingly, we conclude that by filing suit for a declaration of patent ownership and inventorship based on certain contracts and conduct, UNM waived its Eleventh Amendment immunity with respect to all compulsory counterclaims arising from those contracts and conduct. ${ }^{52}$

The UNM Patent Policy, which provides that UNM is the owner of the inventions and patents at issue, also states that the inventors "shall receive a percentage of any income which the University obtains from the exploitation of the invention, such percentage to be determined by negotiation between the President [of UNM] and the inventor[s]." Because the counterclaim for royalties arose out of the same contracts on which UNM's claim of patent ownership is based, the Federal Circuit found the counterclaim to be compulsory, and as such that the district court had improperly dismissed Knight's counterclaim for royalties as barred by the Eleventh Amendment. Accordingly, the lower court's decision was reversed.

Appeal of patent interference decision. In VasCath, Inc. v. Curators of Univ. of Missouri, the Federal Circuit held that a state university's decision to participate in a patent interference proceeding at the PTO results in a waiver of Eleventh Amendment immunity with respect to an appeal of the decision to a federal court. ${ }^{53}$ The dispute between the parties began when the University of Missouri provoked an interference between the University's pending patent application and a patent that had issued to Vas-Cath. After six years of vigorous proceedings, the PTO awarded priority to the University, granted the Vas-Cath claims to the University, and held that Vas-Cath was not entitled to the patent that had it

\footnotetext{
${ }^{50}$ Lapides v. Board of Regents of the University System of Georgia, 535 U.S. 613 (2002).

${ }^{51} I d$. at 1643.

${ }^{52}$ Regents of Univ. of New Mexico, 321 F.3d at 1126.

${ }^{53}$ Vas-Cath, Inc. v. Curators of Univ. of Missouri, 473 F.3d 1376 (Fed. Cir. 2007).
} 
been issued. Vas-Cath appealed the decision to the United States District Court for the Western District of Missouri, but that court dismissed the appeal on Eleventh Amendment grounds. The Federal Circuit reversed, concluding that the Eleventh Amendment did not shield the University from appeal of the PTO's decision in favor of the University. "By requesting and participating in the interference proceeding in the PTO, the University waived its constitutional immunity not only in that proceeding but also in the appeal taken by the losing party."

The Federal Circuit found that "the interference proceeding is a multi-part action with appeal as of right, starting in the PTO and culminating in court. The civil action authorized by $\S 146$ [i.e., appeal to a district court] is not a new claim, but an authorized phase of the interference proceeding that is conducted by the PTO and is subject to judicial review." The Federal Circuit noted that while the district court was correct in its observation that "a state does not waive its sovereign immunity simply by engaging in activities normally conducted by private individuals or corporations," here the University did not simply procure a patent through the routine of ex parte examination, but requested the PTO to conduct litigation-type activity, obtaining a favorable agency ruling for which the statute authorizes judicial review.

The court explained that:

The principles of federalism are not designed for tactical advantage; the Lapides Court recognized the possibility of a state's selective use of "immunity" to achieve litigation advantages.... [T]he question in this case is not whether the University voluntarily participated in the PTO interference, but whether the University can now bar the appeal of the PTO's decision in favor of the University. This argument raises issues not of federalism, but of litigation tactics, for it is undisputed that the PTO decision cannot be reviewed in state court.... We need not consider whether the University intended to gain an unfair tactical advantage, for motives are difficult to evaluate, while jurisdictional rules should be clear. We have concluded that when the University initiated and participated in the interference, its participation included the ensuing statutory review procedures; the University cannot invoke Eleventh Amendment immunity, after it prevailed, to shield the agency decision from review. ${ }^{54}$
Patentability challenges under \$101. In Univ. of Fla. Research Found., Inc. v. Gen. Elec. Co., the Federal Circuit held that a state university had, by virtue of its filing of a lawsuit alleging patent infringement, waived Eleventh Amendment immunity with respect to challenges to the validity of the patent, including patent eligibility challenges under 35 U.S.C. $\S 101 .{ }^{55}$ The plaintiff in the case, University of Florida Research Foundation, Inc. (UFRF), argued that, as an arm of the State of Florida, it enjoyed sovereign immunity under the Eleventh Amendment, and it had not waived that immunity as to the defendant's $\S 101$ eligibility challenge. The Federal Circuit disagreed.

The court noted that waiver extends "not only to the cause of action but also to any relevant defenses and counterclaims." ${ }^{56}$ Under 35 U.S.C. § 282(b), "defenses in any action involving the ... infringement of a patent," include the "condition[s] for patentability" set forth in Part II of Title 35. UFRF argued that these "condition[s] for patentability" include those in $\S \S 102$ and 103, but not those in $\S 101$. But the Federal Circuit had previously held that $\S 282$ is not so limited. In Dealertrack, Inc. v. Huber, for example, the court held that "the 'defenses provided in the statute,' $\S 282$, include not only the 'conditions of patentability' in $\S \S 102$ and 103, but also those in $\S 101 . " 57$ The court held that under Dealertrack, § 282's defenses include a $\S 101$ eligibility challenge like the one raised by the defendant in the instant case.

Inter partes review proceedings. In Regents of the Univ. of Minnesota v. LSI Corp., the Federal Circuit held that Eleventh amendment immunity does not apply to inter partes review proceedings. ${ }^{58}$ The Regents of the University of Minnesota (UMN) sued various parties for patent infringement, and the defendants challenged the validity of the asserted patents through petitions for IPR proceedings. Before the PTO decided whether to institute IPR, UMN filed motions to dismiss each proceeding based on state sovereign immunity. The PTO convened an expanded panel, consisting of three administrative patent judges as well as the Chief Judge, Deputy Chief Judge, and two Vice Chief

\footnotetext{
${ }^{54}$ Id. at $1383-84$.

${ }^{55}$ Univ. of Fla. Research Found., Inc. v. Gen. Elec. Co., 916 F.3d 1363 (Fed. Cir. 2019).

${ }^{56}$ Id. (citing Vas-Cath, Inc. v. Curators of Univ. of Mo., 473 F.3d 1376, 1381 (Fed. Cir. 2007)).

${ }^{57} 674$ F.3d 1315, 1330 n.3 (Fed. Cir. 2012).

${ }^{58}$ Regents of the Univ. of Minnesota v. LSI Corp., 926 F.3d 1327 (Fed. Cir. 2019).
} 
Judges. In each proceeding, the Board concluded that state sovereign immunity applied to IPR proceedings but that UMN waived its immunity by filing suit against petitioners in district court. A concurrence to each of the Board decisions concluded that sovereign immunity was not implicated in part because "[a]t its core, inter partes review is a circumscribed in rem proceeding, in which the Patent Office exercises jurisdiction over the patent challenged, rather than the parties named."

UMN appealed the Board's decisions to the Federal Circuit. The court acknowledged that immunity applies not only to proceedings brought by a private party in an Article III forum but also to agency adjudications brought by private parties that are similar to court adjudications. However, it went on to note that sovereign immunity does not apply to suits brought by the United States, including agency proceedings commenced by the United States. The Supreme Court recognized in $F M C$, for example, that sovereign immunity does not bar an agency from bringing an enforcement action against the state "upon its own initiative or upon information supplied by a private party." 59

The Federal Circuit went on to observe that it had recently addressed the related question of whether tribal sovereign immunity applies to IPR proceedings in Saint Regis Mohawk Tribe v. Mylan Pharmaceuticals Inc., where the court held that it does not. ${ }^{60}$ In Saint Regis, the court held that tribal sovereign immunity did not apply to IPR because the PTO was "acting as the United States in its role as a superior sovereign to reconsider a prior administrative grant and protect the public interest in keeping patent monopolies within their legitimate scope." ${ }^{1}$ The court further held in Saint Regis that "IPR is properly viewed as an agency's reconsideration of a previous patent grant that is aided by information supplied by a third party, and state sovereign immunity does not bar these proceedings." In the present cases, the court concluded that state and tribal sovereign immunity do not differ in a way that is material to the question of whether IPR proceedings are subject to state sovereign immunity. Under the reasoning of the majority and concurrence in Saint Regis, the court concluded that state sovereign immunity does not apply to IPR proceedings.

In closing, the Federal Circuit noted that, although not implicated in the facts of this case, if sovereign immunity barred IPR proceedings against patents obtained by a sovereign, nothing would prevent a state from lending its sovereign immunity to private parties, as the tribe had attempted to do in Saint Regis. The court opined that "[s]uch manipulation would undo Congress' central quality control mechanism in creating post-grant administrative proceedings."

Control of venue. In Bd. of Regents of the Univ. of Texas Sys. v. Bos. Sci. Corp., the Federal Circuit held that a state university cannot rely on Eleventh amendment immunity as a basis for dictating venue in litigation. ${ }^{62}$ The Board of Regents of the University of Texas System (UT) and its licensee TissueGen Inc. sued Boston Scientific Corporation (BSC) in the Western District of Texas for the alleged infringement of patents owned by UT (directed to implantable drug-releasing biodegradable fibers). The district court determined that venue was improper and transferred the case to the District of Delaware. UT appealed the transfer of venue, citing Eleventh Amendment immunity, but the Federal Circuit affirmed, holding that the state sovereignty principles asserted by UT do not grant it the right to bring suit in an otherwise improper venue.

In its attempt to control venue through an assertion of state sovereignty, UT argued that:

Venue is proper in the Western District of Texas because UT is an arm of the State of Texas, has the same sovereign immunity as the State of Texas, it would offend the dignity of the State to require it to pursue persons who have harmed the State outside the territory of Texas, and the State of Texas cannot be compelled to respond to any counterclaims, whether compulsory or not, outside its territory due to the Eleventh Amendment. ${ }^{63}$

In its opening appellate brief, UT asserted that the Eleventh Amendment allows a state "to control where it litigates against a private party." The Federal Circuit disagreed, pointing out that the court had previously held that the Eleventh Amendment applies to suits "against" a state, not suits by a state. ${ }^{64}$ Moreover, as explained by the Supreme Court in Lapides,

[i]t would seem anomalous or inconsistent for a State both (1) to invoke federal jurisdiction,

\footnotetext{
${ }^{59}$ Fed. Mar. Comm'n v. S.C. State Ports Auth., 535 U.S. 743 , 767-68 (2002) (FMC).

${ }^{60}$ Saint Regis Mohawk Tribe v. Mylan Pharmaceuticals Inc., 896 F.3d 1322 (Fed. Cir. 2018).

${ }^{61} I d$. at 1329.

${ }^{62}$ Bd. of Regents of the Univ. of Texas Sys. v. Bos. Sci. Corp., 936 F.3d 1365 (Fed. Cir. 2019).

${ }^{63} \mathrm{Id}$. at 1369 .

${ }^{64}$ Id. at 1375 (citing Eli Lilly, 119 F.3d at 1564).
} 
thereby contending that the "Judicial power of the United States" extends to the case at hand, and (2) to claim Eleventh Amendment immunity, thereby denying that the "Judicial power of the United States" extends to the case at hand. ${ }^{65}$

The Federal Circuit found that its decision in Eli Lilly controls in the present case. Because UT is acting solely as a plaintiff, sovereign immunity does not apply, and UT cannot rely on it to challenge the transfer to the District of Delaware. The court held that sovereign immunity cannot be asserted to challenge a venue transfer in a patent infringement case where a State acts solely as a plaintiff.

The plaintiff is itself a state university. In Univ. of Utah v. Max-Planck-Gesellschaft Zur Forderung Der Wissenschaften E.V., the University of Utah (UUtah) sued multiple plaintiffs, including the University of Massachusetts (UMass), seeking the correction of inventorship on a patent. ${ }^{66}$ UMass filed a motion for dismissal, arguing that, because the dispute was between two States, the Supreme Court had exclusive original jurisdiction. In response, UUtah amended its complaint, substituting four UMass officials (the "Named Officials") in place of UMass, and invoking the doctrine of Ex Parte Young. The Named Officials then moved to dismiss the case, arguing that UUtah's claims against them were barred by sovereign immunity. They also argued that the case should be dismissed for failure to join UMass, which they claimed was an indispensable party. The district court denied the motion, and the defendants appealed.

The district court considered whether sovereign immunity barred UUtah's suit, and if so, whether the Ex Parte Young exception to sovereign immunity applied. On appeal, the Federal Circuit held that "[b]ecause this case does not involve a suit by citizens against a State, there is no sovereign immunity issue here." ${ }^{67}$ The court affirmed the district court's ruling that "this is not a dispute between States falling within the exclusive original jurisdiction of the Supreme Court. UUtah was free to choose between filing this suit in the Supreme Court and filing in federal district court." 68

Writing in dissent, Judge Moore argued that the claims raise a dispute between two States, Utah and Massachusetts, and that Article III of the U.S. Constitution vests the Supreme Court with original jurisdiction over cases of this type, in which a State is a party. For that reason, she would have held that the district court lacked jurisdiction over UUtah's claims. ${ }^{69}$
Dismissal of lawsuit brought by university's exclusive licensee. As discussed above, in Gensetix, Inc. v. Bd. of Regents of Univ. of Texas Sys., UT was successful in asserting its Eleventh Amendment sovereign immunity to resist an attempt by its exclusive licensee (Gensetix) to compel joinder of UT in a patent infringement suit brought against Baylor University. ${ }^{70}$ However, while UT was able to resist joinder, it failed to achieve what appears to have been its primary objective, which was to have the lawsuit dismissed entirely. Initially it seemed that UT was going to succeed with respect to this objective; in the decision below the district court dismissed Gensetix's lawsuit against Baylor, finding that under FRCP 19(b) UT was an indispensable party, and that considerations of "equity and good conscience" dictated that the cause of action should not proceed. A divided Federal Circuit reversed the district court's decision to dismiss the case, finding that the district court had misapplied FRCP 19(b), and that as an exclusive licensee Gensetix should be allowed to proceed with the lawsuit on its own. Writing for the majority, Judge O'Malley based her decision largely on her conclusion that (1) UT was unlikely to be unduly prejudiced by Gensetix enforcing the patent on its own, since the interests of UT and Gensetix in the validity and scope of the patent were aligned; and (2) that Gensetix would suffer a great harm if the case were dismissed, since the company would be left unable to enforce the patent that it had exclusively licensed from UT.

\section{CONCLUDING THOUGHTS}

State universities enjoy a privileged position when it comes to patents, able to fully exploit the patent system as a sword, while largely insulating themselves from liability or judicial intervention through the shield of Eleventh Amendment state sovereign immunity. Pennington Seed provides a good example of this - the University of Arkansas appears to have succeeded in asserting sovereign immunity with respect to its own alleged patent

\footnotetext{
${ }^{65}$ Lapides v. Bd. of Regents of Univ. Sys. of Ga., 535 U.S. 613, 619 (2002).

${ }^{66}$ Univ. of Utah v. Max-Planck-Gesellschaft Zur Forderung der Wissenschaften E.V., 734 F.3d 1315 (Fed. Cir. 2013).

${ }^{67} I d$. at 1325 .

${ }^{68} \mathrm{Id}$.

${ }^{69}$ Id. at $1328-29$.

${ }^{70} 966$ F.3d 1316 (Fed. Cir. 2020).
} 
infringement, while at the same time the university actively pursues the patenting and licensing of its own inventions. ${ }^{71}$ In her Gensetix dissent, Judge Newman voiced her concerns about the potential for state universities to push this advantage too far, echoing the Supreme Court's statements in Lapides regarding the inconsistency and unfairness that could result from allowing a state that voluntarily avails itself of the federal courts to simultaneously claim immunity under the Eleventh Amendment. It is understandable that Congress would seek to address these concerns by abrogating state sovereign immunity, but as discussed above, the Supreme Court has held that the Eleventh Amendment precludes such abrogation.

More than just a shield against liability, universities have learned that the Eleventh Amendment can be used for tactical advantage in litigation. In Tegic Commc'ns, for example, the University was able to control venue by invoking Eleventh Amendment immunity to trump the "customer suit exception" that applies to other patent owners. On the other hand, this article provides a number of examples in which the Federal Circuit has rebuffed attempts by universities to overreach in their interpretation of the extent of the privilege they enjoy under the Eleventh Amendment.

Eleventh Amendment immunity creates particular concerns for entities that seek to engage in collaborative research with universities, or to license university patents. Recall that in Xechem, a collaborative research partner of a university found that state sovereign immunity barred it from seeking judicial recourse to correct the inventorship on a university patent that allegedly failed to list a non-university inventor. In Gensetix, the university almost succeeded in its attempt to use sovereign immunity as a procedural tool to deny its exclusive licensee the opportunity to enforce its licensed patents.

Anyone considering becoming an exclusive licensee of a state university should heed the warning of Gensetix and be fully cognizant of the potential risks posed by state sovereign immunity. In particular, Gensetix suggests that the specific terms of the licensing agreement could prove critical. Under the terms of the agreement between Gensetix and UT, the parties agreed that the university had not waived sovereign immunity. Furthermore, the university retained certain rights to the patented technology, such as for research purposes, rendering the rights transferred less than entirely exclusive. The district court found that these licensing terms supported its determination that the university retained ownership of the patent, and was thus a necessary and indispensable party, but at the same time could not be compelled to join due to sovereign immunity. Clearly, anyone negotiating an "exclusive" license with a university should think twice before agreeing to such terms, and only do so knowing that they could potentially limit the licensees unfettered ability to enforce the licensed patent.

\footnotetext{
${ }^{71}$ A search of the PTO Patent Database on August 30, 2020, for patents listing the "University of Arkansas" as an assignee pulled up 660 patents.
} 